\title{
Article \\ Genetic Improvement of Post-Heading Root Morphology and Physiology Facilitating Yield Increase of japonica Inbred Rice
}

\author{
Tianyao Meng ${ }^{1}$, Xi Chen ${ }^{1}$, Xubin Zhang ${ }^{2}$, Jialin Ge ${ }^{2}$, Guisheng Zhou ${ }^{1}$, Qigen Dai ${ }^{1,2}$ and Huanhe Wei ${ }^{2, *}$ \\ 1 Joint International Research Laboratory of Agriculture and Agri-Product Safety, Institutes of Agricultural \\ Science and Technology Development, The Ministry of Education of China, Yangzhou University, \\ Yangzhou 225009, China; 007126@yzu.edu.cn (T.M.); MX120200673@yzu.edu.cn (X.C.); \\ gszhou@yzu.edu.cn (G.Z.); qgdai@yzu.edu.cn (Q.D.) \\ 2 Jiangsu Co-Innovation Center for Modern Production Technology of Grain Crops, Research Institute of Rice \\ Industrial Engineering Technology, Yangzhou University, Yangzhou 225009, China; \\ MZ120201218@yzu.edu.cn (X.Z.); dx120210104@yzu.edu.cn (J.G.) \\ * Correspondence: 006931@yzu.edu.cn; Tel.: +86-514-8797-0292
}

Citation: Meng, T.; Chen, X.; Zhang, X.; Ge, J.; Zhou, G.; Dai, Q.; Wei, H.

Genetic Improvement of

Post-Heading Root Morphology and Physiology Facilitating Yield Increase of japonica Inbred Rice. Agronomy 2021, 11, 2457. https://doi.org/ 10.3390/agronomy11122457

Academic Editor: José Miguel Soriano

Received: 29 October 2021

Accepted: 29 November 2021

Published: 1 December 2021

Publisher's Note: MDPI stays neutral with regard to jurisdictional claims in published maps and institutional affiliations.

Copyright: (c) 2021 by the authors. Licensee MDPI, Basel, Switzerland. This article is an open access article distributed under the terms and conditions of the Creative Commons Attribution (CC BY) license (https:// creativecommons.org/licenses/by/ $4.0 /)$.

\begin{abstract}
Since genetic improvement greatly promoted an increased yield japonica inbred rice in east China after the 1990s, better root characteristics were certainly expected. In 2018 and 2019, nine japonica inbred rice released in the 1990s, 2000s, and 2010s were investigated to evaluate the changes in root morpho-physiology and identify root traits that contributed to the positive yield trends during the genetic process. The 2010's rice had 8.0 and 4.3\% higher grain yield than the 1990's and the 2000's rice, respectively $(p<0.05)$. Genetic yield gain was mainly attributed to the increased spikelets per panicle. Compared with the 1990's and the 2000's rice, the 2010's rice had higher shoot biomass at heading and maturity $(p<0.05)$, as well as root biomass $(p<0.05)$, especially for root biomass of 15-30 cm soil depth. Leaf area index (LAI), soil-plant analysis development (SPAD) values, and leaf photosynthetic rate at middle grain-filling period (MGP) and late grain-filling period (LGP) were all increased. The 2010's rice had consistently higher root length and volume, root oxidation activity, and root bleeding rate at MGP and LGP than the 1990's and the 2000's rice $(p<0.05)$. Positive correlations were detected between root length and volume, root oxidation activity, and root bleeding rate at MGP, LGP, and SPAD values, leaf photosynthetic rate at MGP and LGP, and higher shoot biomass accumulation after heading and grain yield $(p<0.05$ or $p<0.01)$. The present study implied that genetic improvement optimized post-heading root morphology and physiology, which maintained shoot stay-green and facilitated biomass accumulation and yield increase in japonica inbred rice during the genetic process since the 1990s.
\end{abstract}

Keywords: genetic improvement; grain yield; japonica inbred rice; root morphology and physiology

\section{Introduction}

Rice is a staple grain crop worldwide, therefore increasing rice production is a major strategy for ensuring food security [1]. Genetic improvement is recognized as a key driver in improving rice yield [2]. A modeling study estimated genetic improvement contributed $74 \%$ to the total increased rice production, after the 1980s, in China [3].

Genetic yield gain was intensively studied across rice-growing countries [4-6]. Most existing literature suggested a pronounced yield increase over years. For instance, Breseghllo et al. [4] reported an increased annual yield of $19.1 \mathrm{~kg} \mathrm{ha}^{-1}$ among upland rice, bred from 1984 to 2009, in Brazil. The increasing grain yield during genetic improvement was associated with enlarged sink potential through spikelets per panicle [6], increased total biomass, and/or harvest index [4,7], better leaf stay-green and more erect plant canopy [8,9], and optimized source-sink balance [10]. Such above studies focused mainly on the shoot traits that contributed directly to progressive yield gain during the genetic improvement. 
The root is a critical plant organ and serves multiple roles, including anchorage and acquisition of essential nutrients and water, and adaption to the changing environments [11]. The effects of genetic improvements on root characteristics were reported in maize [12,13], soybean [14], and wheat [15,16]. For example, Ning et al. [12] reported that the genetic process increased the length and biomass weight of deeper roots, which facilitated higher grain yield in modern maize varieties. For rice, Zhang et al. [17] concluded that improved root and shoot growth were closely associated with an increased yield of indica inbred and indica hybrid rice. Still, little attention is paid to changes of root characteristics during the genetic process of japonica inbred rice, another critical cultivar type in production in China.

The last three decades have witnessed rapid development in cultivation area of japonica inbred rice, especially in east China. Jiangsu, located in east China, is an important riceproducing area in China, and its dominated rice type has changed from indica hybrid rice to japonica inbred rice since the 1990s. The proportion of japonica inbred rice planting area has increased from $10 \%$ in the 1990 s to $90 \%$ nowadays [18]. Such a pronounced genetic improvement contributed greatly to boosting rice production, which helped increase rice yield $\left(t \mathrm{ha}^{-1}\right.$ ) from 7.5 in the 1990s to 8.6 today on a provincial scale [19]. Since grain yield was greatly promoted during the genetic process of japonica inbred rice in Jiangsu after the 1990s, an improved root system should be expected. However, such a hypothesis still needs to be confirmed.

The present study had two main objectives: (1) to evaluate changes and differences in root characteristics of japonica inbred rice released in the 1990s, 2000s, and 2010s; (2) to verify the hypothesis that genetic progress modified root morpho-physiology of japonica inbred rice.

\section{Materials and Methods}

\subsection{Experimental Site, Rice Cultivar, Field Design, and Crop Establishment}

Field experiments were implemented at Yangzhou University, Jiangsu, east China in 2018 and 2019. In this study, rice was grown from May to October; generally, rice in 2018 experienced higher temperatures, sunshine hours, and rainfall than the corresponding in 2019. The soil in the experimental field has a sandy loam texture with $18.3 \mathrm{~g}$ organic carbon $\mathrm{kg}^{-1}, 1.1 \mathrm{~g}$ total nitrogen $(\mathrm{N}) \mathrm{kg}^{-1}, 31.8 \mathrm{mg}$ Olsen phosphorus $(\mathrm{P}) \mathrm{kg}^{-1}$, and $85.1 \mathrm{mg}$ available potassium $(\mathrm{K}) \mathrm{kg}^{-1}$ in the $0-20 \mathrm{~cm}$ soil layer.

Nine japonica inbred rice cultivars were adopted in this study and classified to three types, i.e., the 1990s, 2000s, and 2010s, according to the releasing year. The 1990's rice cultivars were Wuyunjing 3, Zhendao 88, and Zaofeng 9; the 2000's rice cultivars were Wujing 13, Huaidao 9, and Nanjing 44; the 2010's rice cultivars were Zhendao 18, Nanjing 9108, and Nanjing 2728. These rice cultivars were chosen because they were all released by local breeding institutes, and they were widely adopted by local farmers during historical periods. For instance, the cumulative planting area of Wuyujing 3 was up to 6.1 million hectares by the end of 2019, which was the most popular rice cultivar in the 1990s in east China (www.ricedata.cn, accessed on 10 August 2021). In recent years, Nanjing 9108, with excellent cooking and eating qualities, was grown widely [20], with a cumulative growing area of 1.8 million hectares as of 2019 (www.ricedata.cn, accessed on 10 August 2021). The rice cultivars were considered representative during the genetic improvement of japonica inbred rice since the 1990s, and they were always chosen as the control in rice cultivar regional trials conducted in Jiangsu, east China. Besides, these rice cultivars shared a similar heading date ranging from $8 / 20$ (month/day) to $8 / 25$ (month/day), as well as growth pattern (total growth period ranged from $150 \mathrm{~d}$ to $156 \mathrm{~d}$ ). The detailed information on the releasing year, cross information, and accumulative planting area of these rice cultivars were presented in Table 1. Seeds of these nine japonica inbred rice were kindly provided by breeding institutes. 
Table 1. The information on releasing year, cross information, and cumulative planting area of rice cultivars.

\begin{tabular}{cccc}
\hline Cultivar & Releasing Year & Cross Information & $\begin{array}{c}\text { Cumulative Planting } \\
\text { Area (Mha) }\end{array}$ \\
\hline Wuyujing 3 & 1992 & Zhongdan 1/79-51 $\times$ Zhongdan 1/Yangjing 1 & 6.1 \\
Zhendao 88 & 1997 & Yuezhiguang $\times$ 2507-4 & 0.5 \\
Zaofeng 9 & 1997 & Wufujing/Zhongdan 1 $\times$ Nonglin 205 & 1.0 \\
Wujing 13 & 2003 & $791 \times$ SR 21 & 0.3 \\
Huaidao 9 & 2006 & Huai 9712 & 0.5 \\
Nanjing 44 & 2007 & Nanjing 38 & 0.5 \\
Zhendao 18 & 2013 & Zhendao 99 $\times$ Wuyunjing 7 & 0.2 \\
Nanjing 9108 & 2013 & Wuxiangjing 14 $\times$ Guandong 194 & 1.8 \\
Nanjing 2728 & 2018 & Wujing 15 $\times$ Nanjing 5055 & 0.1 \\
\hline
\end{tabular}

The information is available from the website http:/ / www.ricedata.cn, accessed on 10 August 2021.

A randomized block design was used in this field experiment, and each plot was $6 \times 5 \mathrm{~m}^{2}$ in size, with three replications during both study years. Rice seeds were sown in seedbeds on 23 May and transplanted with four seedlings per hill at a spacing of $30 \mathrm{~cm} \times 12 \mathrm{~cm}$ on 12 June during two years. The plots were fertilized with total rates of $270 \mathrm{~kg} \mathrm{~N} \mathrm{ha}^{-1}, 180 \mathrm{~kg} \mathrm{P} \mathrm{ha}^{-1}$, and $135 \mathrm{~kg} \mathrm{~K} \mathrm{ha}^{-1}$. As a basal dressing, $81 \mathrm{~kg} \mathrm{~N} \mathrm{ha}^{-1}$, $180 \mathrm{~kg} \mathrm{P} \mathrm{ha}^{-1}$, and $135 \mathrm{~kg} \mathrm{Kha}^{-1}$ were applied at 1 day before transplanting; $81 \mathrm{~kg} \mathrm{~N} \mathrm{ha}^{-1}$, $54 \mathrm{~kg} \mathrm{~N} \mathrm{ha}^{-1}$, and $54 \mathrm{~kg} \mathrm{~N} \mathrm{ha}^{-1}$ were applied as a topdressing at 1 week after transplanting, panicle initiation, and penultimate-leaf appearance stage, respectively. The irrigation regime adopted in the field experiment followed alternate wetting and drying cycles [21]. Chemical controls of pests, disease, and weed were performed following local practices.

\subsection{Sampling and Measurement}

At jointing, heading, and maturity, plants of three hills with soil blocks $(30 \mathrm{~cm}$ long, $12 \mathrm{~cm}$ wide, and $30 \mathrm{~cm}$ deep) were collected to determine the biomass of shoot and root. The shoot parts were placed well in Kraft paper bags, and shoot biomass was recorded after $80 \mathrm{~h}$ of oven-drying at $75^{\circ} \mathrm{C}$. The root parts were cut into two segments with $15 \mathrm{~cm}$ intervals, then these parts were rinsed clean and oven-dried for $80 \mathrm{~h}$ at $75{ }^{\circ} \mathrm{C}$ to weigh root biomass.

Plants of four hills were collected at early grain-filling period (EGP, 5-6 days after heading), middle grain-filling period (MGP, 26-27 days after heading), and late grain-filling period (LGP, 47-48 days after heading) to measure leaf area index (LAI), soil-plant analysis development (SPAD) values, and leaf photosynthetic rate. LAI was measured through a Leaf Area Meter (LI-3100C, Lincoln, NE, USA). The SPAD meter (SPAD-502 plus, Konica Minolta Sensing, Inc., Osaka, Japan) was used for measurement of SPAD values of the upper three leaves around 14:30 $\mathrm{h}$ to $16: 00 \mathrm{~h}$ under a clear sky. Flag leaf photosynthetic rate was performed by three portable photosynthetic instruments (LICOR-6400, Lincoln, NE, USA) around 9:30 $\mathrm{h}$ to 11:00 $\mathrm{h}$ under sunny conditions.

At EGP, MGP, and LGP, plants of three hills with soil blocks $(30 \mathrm{~cm}$ long, $12 \mathrm{~cm}$ wide, and $30 \mathrm{~cm}$ deep) were collected to determine root length, volume, and root oxidation activity. The roots were rinsed clean for measurement of root length and volume through an LA-S Root Analysis Software (Wanshen Ltd., Hangzhou, China). Meanwhile, root oxidation activity was determined by measuring the oxidation of alpha-naphthylamine $(\alpha-\mathrm{NA})$ [22]. Besides, root bleeding rate was determined at EGP, MGP, and LGP, and the specific measurement process was described well in our previous study [23].

At maturity, two hundred representative hills of rice plants in each plot, excluding border plants, were sampled for the determination of grain yield (expressed at 14\% moisture). One hundred representative hills of rice plants in each plot were collected for measuring panicles per $\mathrm{m}^{2}$, spikelets per panicle, filled-grain percentage, and 1000-grain weight. The filled-grain percentage was calculated as the ratio of filled grains, selected in a salt solution with a gravity of 1.06 . 


\subsection{Statistical Analysis}

Data were subjected to a two-way analysis of variance (ANOVA) to assess the effects of year, cultivar type, and interactions between the two on the grain yield and its components, biomass of shoot and root, LAI, leaf photosynthetic rate, SPAD values, root length and volume, root oxidation activity, and root bleeding rate. When the treatment means were different, the LSD test was performed to identify significant differences at $p<0.05$. Data of three cultivars in the same cultivar type were averaged because there were no significant differences in all determined parameters among three cultivars in the same cultivar type. All data analyses were conducted with SPSS 17.0 Software (SPSS Inc., Chicago, IL, USA).

\section{Results}

\subsection{Grain Yield}

Grain yield of the 2010 's rice was averaged $10.9 \mathrm{tha}^{-1}$, and it was 8.0 and $4.3 \%$ higher than the 1990's and the 2000's rice across two years, respectively $(p<0.05)$. There were differences in panicles per $\mathrm{m}^{2}$, spikelets per panicle, and filled-grain percentage among rice cultivar types $(p<0.01)$, while there was no difference in 1000-grain weight among year, cultivar type, and their interaction ( $p \geq 0.05)$. With the cultivar improvement, spikelets per panicle increased, while panicles per $\mathrm{m}^{2}$ and filled-grain percentage decreased. For example, spikelets per panicle of the 2010's rice was averaged 161 across two years, and it was $28.9 \%$ and $13.0 \%$ higher than that of the 1990's and the 2000 's rice, respectively $(p<0.01)$ (Table 2).

Table 2. Grain yield and its components of cultivar types.

\begin{tabular}{|c|c|c|c|c|c|c|}
\hline Year & Cultivar Type & $\begin{array}{l}\text { Grain Yield } \\
\left(t \mathrm{ha}^{-1}\right)\end{array}$ & $\begin{array}{l}\text { Panicles } \\
\text { per } \mathbf{m}^{2}\end{array}$ & $\begin{array}{l}\text { Spikelets } \\
\text { per Panicle }\end{array}$ & $\begin{array}{c}\text { Filled-Grain } \\
\text { Percentage (\%) }\end{array}$ & $\begin{array}{l}\text { 1000-Grain Weight } \\
\text { (g) }\end{array}$ \\
\hline \multirow[t]{3}{*}{2018} & 1990s & $10.1 \pm 0.2 b$ & $319 \pm 12 \mathrm{a}$ & $128 \pm 6 c$ & $89.6 \pm 0.5 \mathrm{ab}$ & $27.6 \pm 0.3 \mathrm{a}$ \\
\hline & $2000 s$ & $10.4 \pm 0.2 \mathrm{~b}$ & $307 \pm 10 \mathrm{ab}$ & $143 \pm 7 b$ & $89.9 \pm 0.6 \mathrm{a}$ & $27.0 \pm 0.4 \mathrm{a}$ \\
\hline & $2010 s$ & $10.8 \pm 0.2 \mathrm{a}$ & $290 \pm 8 b$ & $158 \pm 6 a$ & $88.5 \pm 0.7 b$ & $27.3 \pm 0.2 \mathrm{a}$ \\
\hline \multirow[t]{4}{*}{2019} & 1990s & $10.0 \pm 0.3 c$ & $322 \pm 5 a$ & $121 \pm 6 c$ & $90.1 \pm 0.8 \mathrm{a}$ & $27.5 \pm 0.4 \mathrm{a}$ \\
\hline & $2000 s$ & $10.4 \pm 0.3 b$ & $310 \pm 6 a$ & $141 \pm 6 b$ & $89.1 \pm 0.3 b$ & $27.3 \pm 0.3 \mathrm{a}$ \\
\hline & $2010 \mathrm{~s}$ & $10.9 \pm 0.2 \mathrm{a}$ & $279 \pm 14 b$ & $163 \pm 4 \mathrm{a}$ & $88.7 \pm 0.4 b$ & $26.8 \pm 0.4 b$ \\
\hline & & & \multicolumn{2}{|c|}{ Analysis of variance (ANOVA) } & & \\
\hline \multirow{2}{*}{\multicolumn{2}{|c|}{$\begin{array}{c}\text { Year } \\
\text { Cultivar type }\end{array}$}} & ns & ns & ns & ns & ns \\
\hline & & $* *$ & $* *$ & $* *$ & ** & ns \\
\hline \multicolumn{2}{|c|}{ Year $\times$ Cultivar type } & ns & ns & $\mathrm{ns}$ & ns & ns \\
\hline
\end{tabular}

Data are mean values $(n=3) \pm$ standard deviation. Data followed by different lowercase letters, within the same year and the same column, are significantly different at $p<0.05$ level. ns, not significant, and ${ }^{* *}$, significant at $p<0.01$ level, based on LSD test.

\subsection{Biomass of Shoot and Root}

No difference was detected in shoot biomass weight at jointing among year, cultivar type, and their interaction $(p \geq 0.05)$. Shoot biomass weight, at maturity of the 2010's rice, was averaged $19.4 \mathrm{tha}^{-1}$, and it was $5.7 \%$ and $4.3 \%$ higher $(p<0.05)$ than that of the 1990 's and the 2000's rice across two years, respectively. Similarly, the 2010's rice had higher shoot biomass at maturity than the 1990's and the 2000's rice $(p<0.05)$. No difference was detected for shoot biomass weight at maturity between the 1990's and the 2000's rice ( $p \geq 0.05)$, while the 2000's rice had a higher harvest index than the 1990's rice $(p<0.05)$. Compared with the 2000's rice, the 2010's rice showed an increment of shoot biomass weight at maturity $(p<0.05)$, while a non-significant increment of harvest index $(p \geq 0.05)$. Compared with the 1990's and the 2000's rice, the 2010's rice had more shoot biomass accumulation from heading to maturity $(p<0.05)$ (Table 3$)$.

Root biomass weight at jointing was not different among cultivar types during two years $(p \geq 0.05)$. Compared with the 1990's and the 2000's rice, the 2010's rice had more root biomass weight at heading and maturity $(p<0.05)$. For example, root biomass weight at 
maturity of the 2010 's rice was averaged $1.3 \mathrm{tha}^{-1}$, and it was $17.7 \%$ and $6.4 \%$ higher than that of the 1990's and the 2000's rice across two years, respectively $(p<0.05)$ (Figure 1).

Table 3. Shoot biomass weight, harvest index, and shoot biomass accumulation of cultivar types.

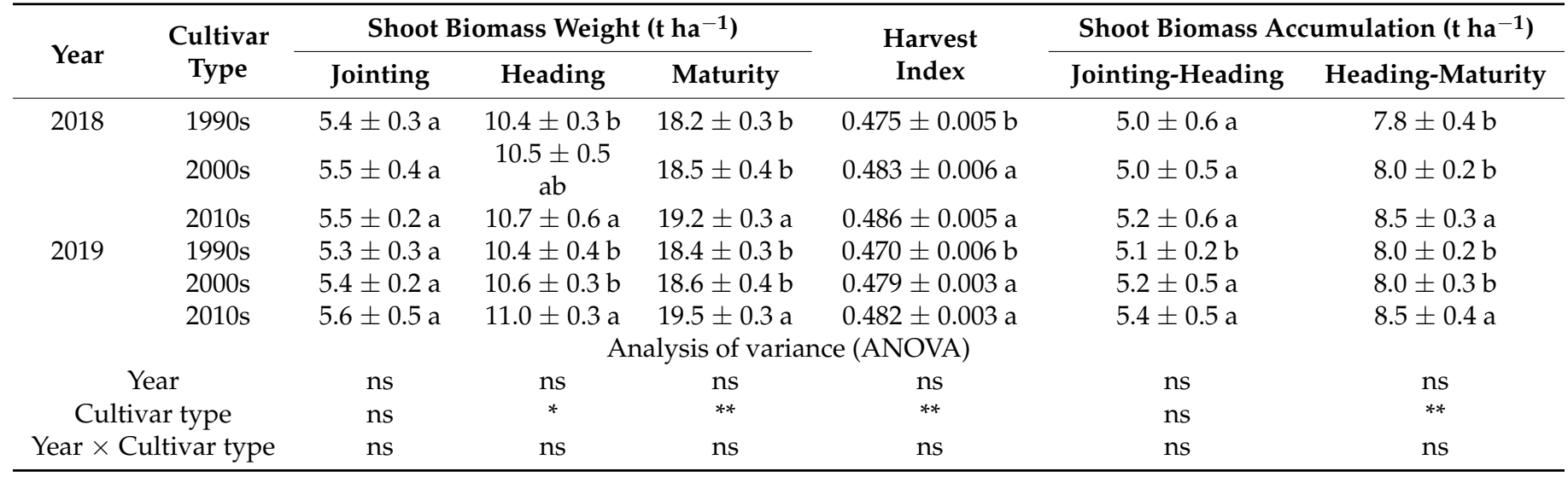

Data are mean values $(n=3) \pm$ standard deviation. Data followed by different lowercase letters within the same year and the same column are significantly different at $p<0.05$ level: ns, not significant, ${ }^{*}$, significant at $p<0.05$ level, and ${ }^{* *}$, significant at $p<0.01$ level, based on LSD test.
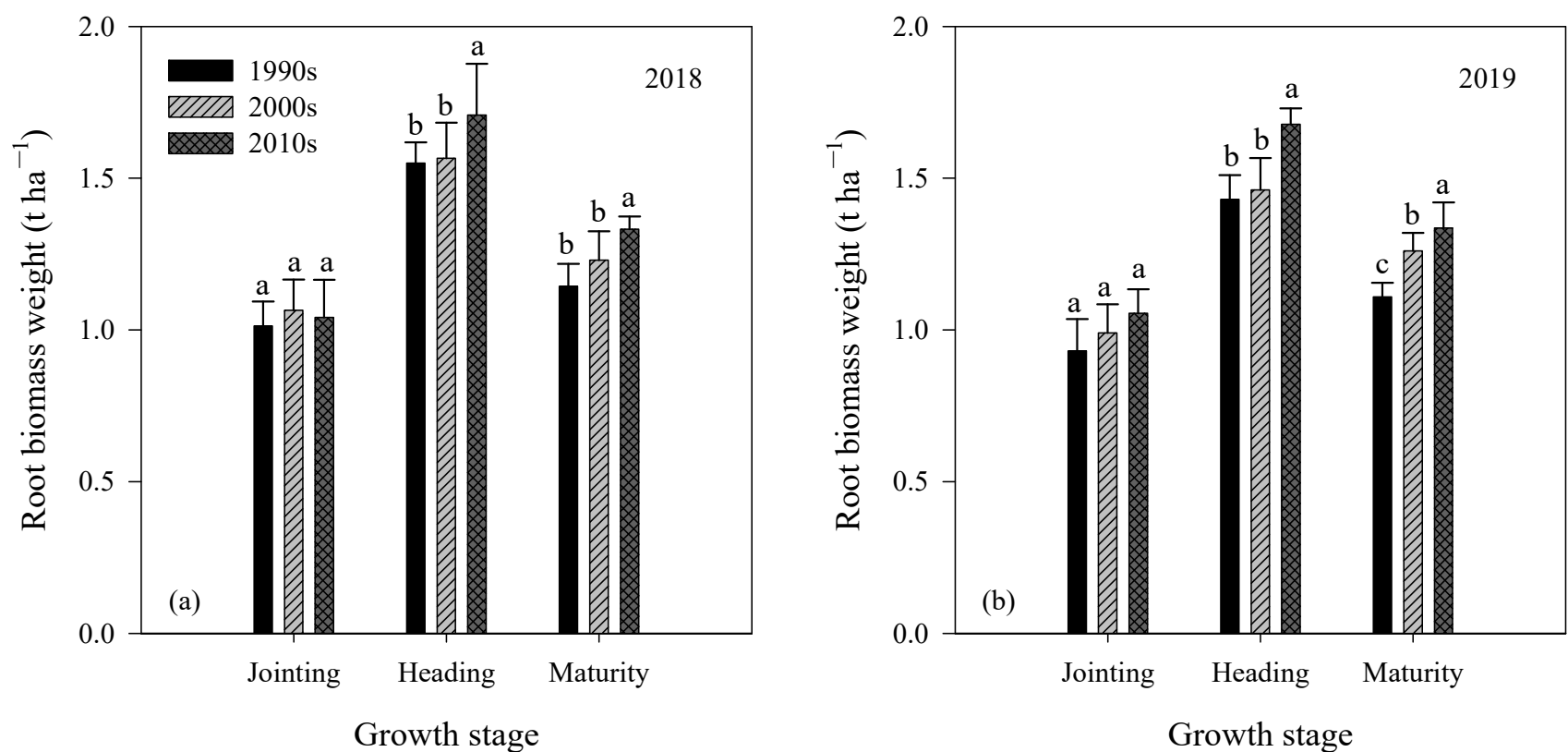

Figure 1. Root biomass weight at the main growth stages $(\mathbf{a}, \mathbf{b})$ of cultivar types. Data are mean values $(n=3) \pm$ standard deviation. Different lowercase letters above the histogram within the same growth stage indicate statistical significance at $p<0.05$ level.

There were no consistent trends in root biomass weight of $0-15 \mathrm{~cm}$ and $15-30 \mathrm{~cm}$ soil depth at jointing among three cultivar types. Root biomass weight of $0-15 \mathrm{~cm}$ and 15-30 cm soil depth, at heading and maturity, increased with cultivar improvement. Compared with the 1990's and the 2000's rice, the 2010's rice had higher root biomass for 15-30 cm soil depth at heading and maturity $(p<0.05)$. For instance, root biomass of $15-30 \mathrm{~cm}$ soil depth, at maturity of the 2010 's rice, was $43.9 \%$ and $22.1 \%$ higher than that of the 1990's and the 2000's rice, respectively (Table 4). 
Table 4. Root biomass weight distributed in $0-15 \mathrm{~cm}$ and $15-30 \mathrm{~cm}$ soil depth of cultivar types.

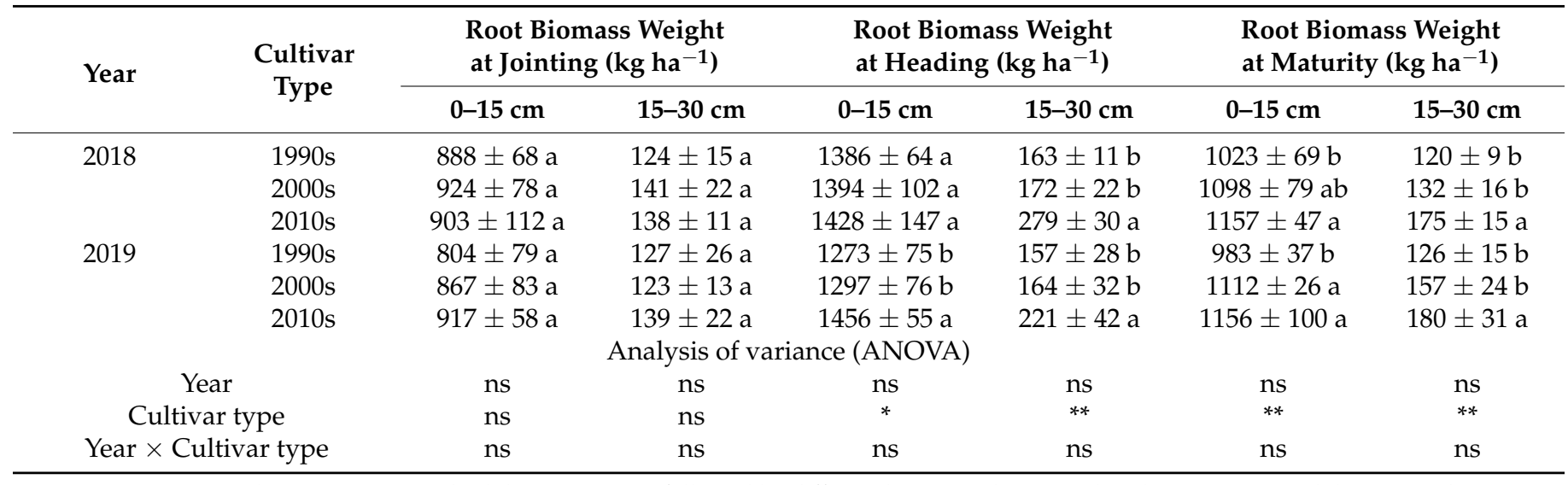

Data are mean values $(n=3) \pm$ standard deviation. Data followed by different lowercase letters within the same year and the same column are significantly different at $p<0.05$ level: ns, not significant, ${ }^{*}$, significant at $p<0.05$ level, and ${ }^{* *}$, significant at $p<0.01$ level, based on LSD test.

\subsection{LAI, Leaf Photosynthetic Rate, and SPAD Values}

There exist differences in LAI after heading among cultivar types $(p<0.01)$. For instance, LAI at EGP of the 2010's rice was averaged 7.8, and it was 30.3\% and 8.4\% higher than that of the 1990's and the 2000's rice across two years, respectively $(p<0.05)$ (Table 5).

Table 5. Leaf area index (LAI) after heading of cultivar types.

\begin{tabular}{|c|c|c|c|c|}
\hline \multirow{2}{*}{ Year } & \multirow{2}{*}{ Cultivar Type } & \multicolumn{3}{|c|}{ Leaf Area Index (LAI, $\left.\mathrm{m}^{2} \mathrm{~m}^{-2}\right)$} \\
\hline & & EGP & MGP & LGP \\
\hline \multirow[t]{3}{*}{2018} & 1990s & $5.8 \pm 0.3 c$ & $4.1 \pm 0.3 \mathrm{c}$ & $2.3 \pm 0.2 b$ \\
\hline & $2000 s$ & $7.2 \pm 0.3 b$ & $5.0 \pm 0.2 b$ & $2.6 \pm 0.2 \mathrm{ab}$ \\
\hline & $2010 s$ & $7.8 \pm 0.2 \mathrm{a}$ & $5.4 \pm 0.1 \mathrm{a}$ & $2.9 \pm 0.2 \mathrm{a}$ \\
\hline \multirow[t]{4}{*}{2019} & $1990 s$ & $6.1 \pm 0.2 \mathrm{c}$ & $4.3 \pm 0.1 \mathrm{c}$ & $2.4 \pm 0.2 \mathrm{~b}$ \\
\hline & $2000 s$ & $7.1 \pm 0.4 b$ & $5.0 \pm 0.2 b$ & $2.6 \pm 0.2 b$ \\
\hline & $2010 s$ & $7.7 \pm 0.2 \mathrm{a}$ & $5.5 \pm 0.1 \mathrm{a}$ & $3.0 \pm 0.2 \mathrm{a}$ \\
\hline & \multicolumn{4}{|c|}{ Analysis of variance (ANOVA) } \\
\hline & & ns & ns & ns \\
\hline \multicolumn{2}{|c|}{ Cultivar type } & $* *$ & $* *$ & $* *$ \\
\hline \multicolumn{2}{|c|}{ Year $\times$ Cultivar type } & ns & ns & ns \\
\hline
\end{tabular}

$\overline{\text { EGP, early grain-filling period; MGP, middle grain-filling period; LGP, late grain-filling period. Data are mean }}$ values $(n=3) \pm$ standard deviation. Data followed by different lowercase letters within the same year and the same column are significantly different at $p<0.05$ level: ns, not significant, and ${ }^{* *}$, significant at $p<0.01$ level, based on LSD test.

A non-significant difference was found for flag leaf photosynthetic rate at EGP, among three cultivar types, for both years ( $p \geq 0.05$ ). Compared with the 1990's and the 2000's rice, the 2010 's rice had a $10.2 \%$ and $4.1 \%$ higher flag leaf photosynthetic rate at MGP, and it was $16.9 \%$ and $9.8 \%$ higher at LGP, respectively $(p<0.05)$. The 2010 's rice had consistently higher SPAD values of the upper three leaves at MGP than the 1990's and the 2000's rice, and a similar trend was detected at LGP $(p<0.05)$ (Figure 2$)$.

\subsection{Root Length and Volume, Root Oxidation Activity, and Root Bleeding Rate}

There exist differences in root length and root volume after heading among cultivar types $(p<0.01)$. The 2010's rice had a longer root length than the 1990's rice at EGP and MGP, as well as more than the 1990's and 2000's rice at LGP $(p<0.05)$. Root volume at EGP of the 2010's rice was higher than the 1990's rice $(p<0.05)$. The 2010's rice exhibited higher root volume at EGP than the 1990's rice, as well as more than the 1990's and 2000's rice at MGP and LGP during two years $(p<0.05)$ (Table 6). 

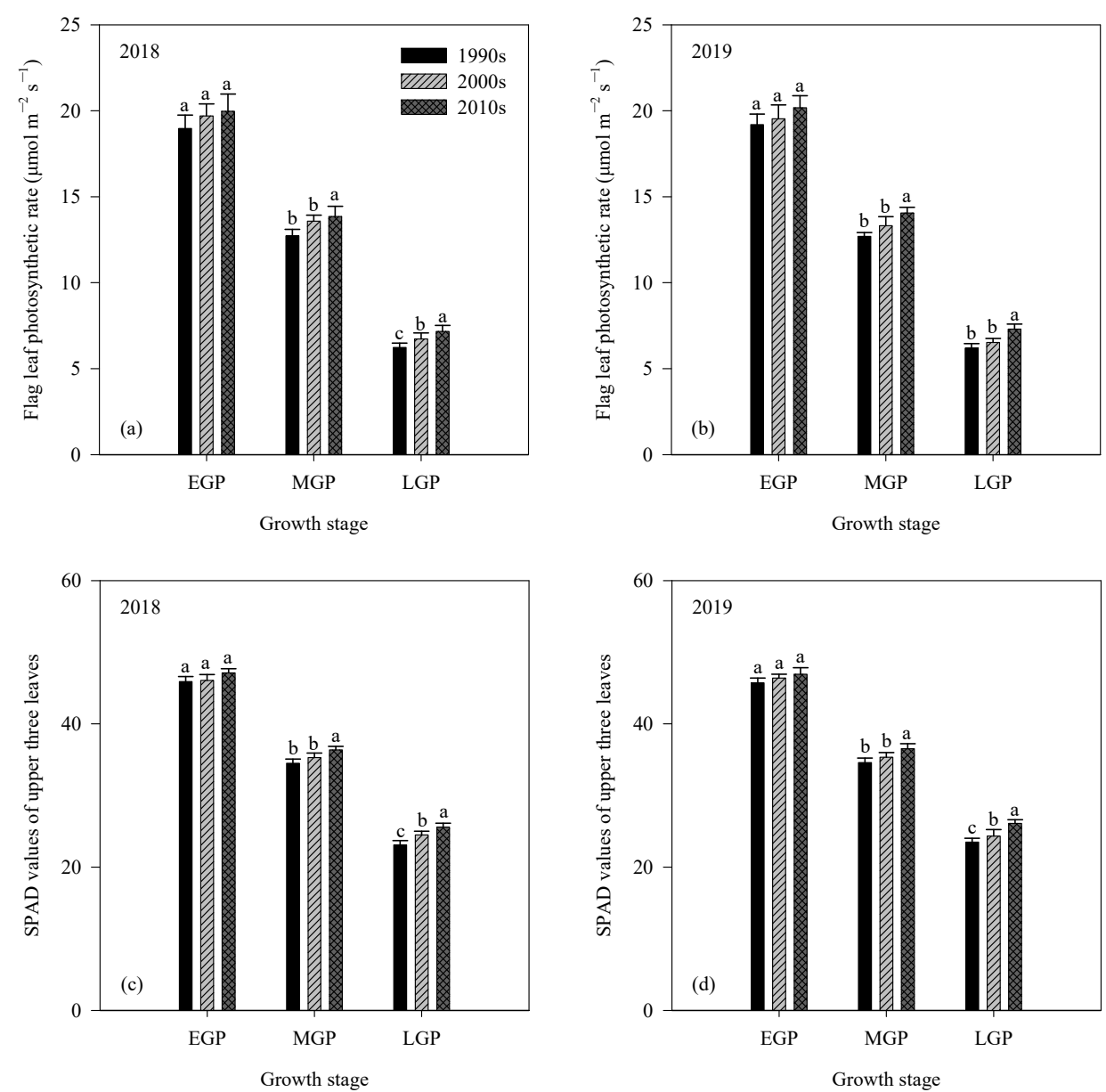

Figure 2. Flag leaf photosynthetic rate $(\mathbf{a}, \mathbf{b})$ and soil-plant analysis development (SPAD) values of the upper three leaves (c,d) after heading of cultivar types. SPAD, soil-plant analysis development; EGP, early grain-filling period; MGP, middle grain-filling period; LGP, late grain-filling period. Data are mean values $(n=3) \pm$ standard deviation. Different lowercase letters above the histogram, within the same growth stage, indicate statistical significance at $p<0.05$ level.

Table 6. Root length and volume after heading of cultivar types.

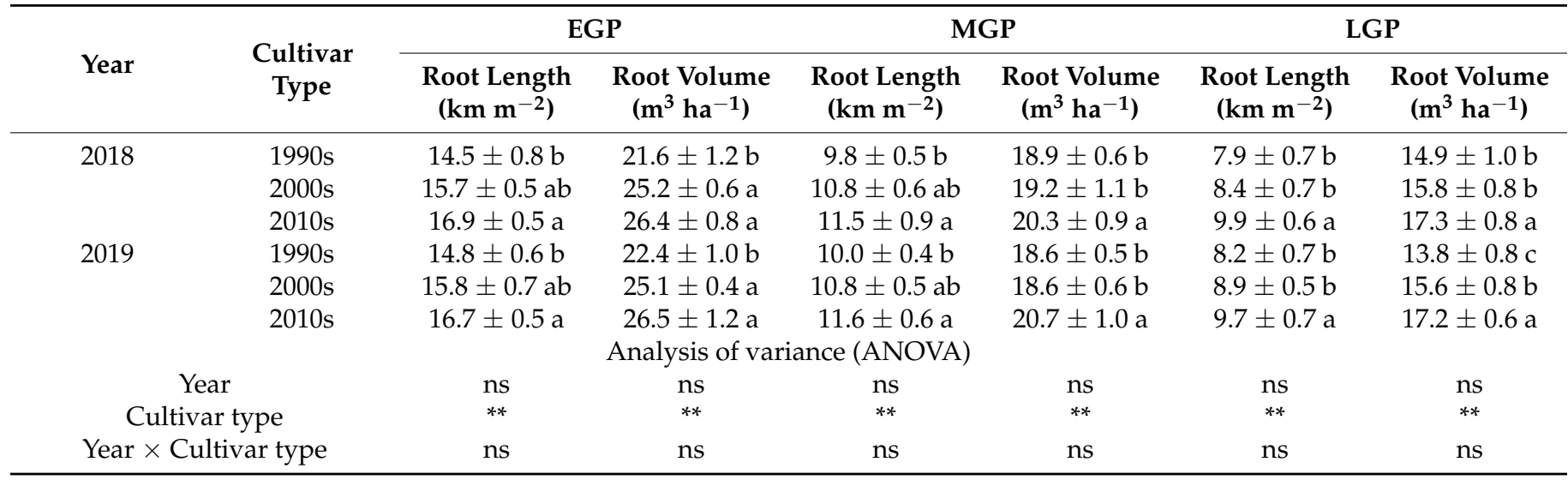

EGP, early grain-filling period; MGP, middle grain-filling period; LGP, late grain-filling period. Data are mean values $(n=3) \pm$ standard deviation. Data followed by different lowercase letters within the same year and the same column are significantly different at $p<0.05$ level: ns, not significant, and **, significant at $p<0.01$ level, based on LSD test.

The 2010's rice showed higher root oxidation activity at EGP than the 1990's and the 2000's rice in 2019, while such a trend was not observed in 2018. Compared with the 1990's 
and the 2000's rice, the 2010's rice had higher root oxidation activity at MGP and LGP $(p<0.05)$. There is no consistent trend for root bleeding rate at EGP among three cultivar types. The 2010's rice exhibited a higher root bleeding rate at MGP and LGP, compared with the 1990's and the 2000's rice $(p<0.05)$ (Figure 3).
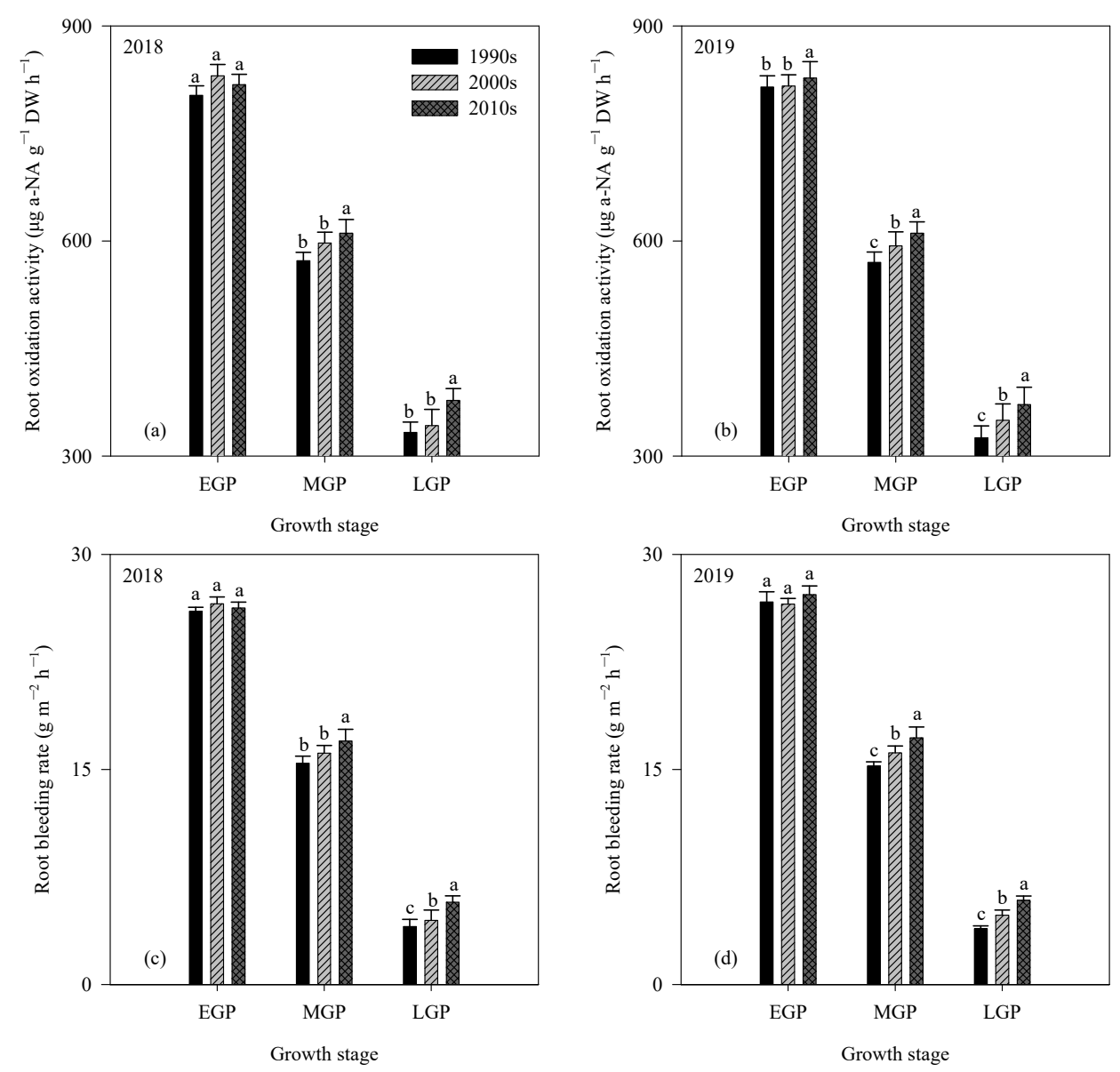

Figure 3. Root oxidation activity $(\mathbf{a}, \mathbf{b})$ and root bleeding rate $(\mathbf{c}, \mathbf{d})$ of cultivar types. $\alpha$-NA, alphanaphthylamine; EGP, early grain-filling period; MGP, middle grain-filling period; LGP, late grainfilling period. Data are mean values $(n=3) \pm$ standard deviation. Different lowercase letters above the histogram, within the same growth stage, indicate statistical significance at $p<0.05$ level.

\subsection{Correlation Analysis}

There existed a positive correlation between root biomass and shoot biomass at heading and maturity $(p<0.05$ or $p<0.01)$. Root biomass weight at heading and maturity were both positively related to rice grain yield $(p<0.01)$ (Table 7$)$. Root length and volume, root oxidation activity, and root bleeding rate at MGP and LGP were positively correlated with leaf photosynthetic rate and SPAD values at MGP and LGP, shoot biomass accumulation after heading, and grain yield ( $p<0.05$ or $p<0.01)$ (Table 8$)$.

Table 7. Correlations between root biomass weight and shoot biomass weight and grain yield.

\begin{tabular}{rrcccc}
\hline \multirow{2}{*}{ Item } & & \multicolumn{3}{c}{ Shoot Biomass Weight } & \multirow{2}{*}{ Grain Yield } \\
\cline { 3 - 5 } & & Jointing & Heading & Maturity & \\
\hline \multirow{3}{*}{ Root biomass weight } & Jointing & $0.49^{*}$ & 0.25 & 0.28 & 0.28 \\
& Heading & 0.17 & $0.48^{*}$ & $0.52^{*}$ & $0.60^{* *}$ \\
& Maturity & 0.42 & $0.52^{*}$ & $0.83^{* *}$ & $0.77^{* *}$ \\
\hline
\end{tabular}

*, significant at $p<0.05$ level, and ${ }^{* *}$, significant at $p<0.01$ level. 


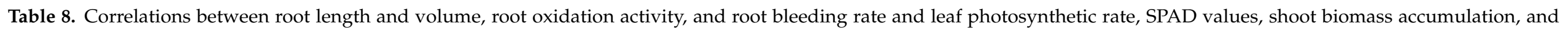
grain yield.

\begin{tabular}{|c|c|c|c|c|c|c|c|c|c|}
\hline & \multirow[b]{2}{*}{ Item } & \multicolumn{2}{|l|}{ EGP } & \multicolumn{2}{|l|}{ MGP } & \multicolumn{2}{|l|}{ LGP } & \multirow{2}{*}{$\begin{array}{l}\text { Shoot Biomass } \\
\text { Accumulation from } \\
\text { Heading to Maturity }\end{array}$} & \multirow[b]{2}{*}{ Grain Yield } \\
\hline & & $\begin{array}{c}\text { Leaf Photosynthetic } \\
\text { Rate }\end{array}$ & $\begin{array}{l}\text { SPAD } \\
\text { Values }\end{array}$ & $\begin{array}{c}\text { Leaf Photosynthetic } \\
\text { Rate }\end{array}$ & $\begin{array}{l}\text { SPAD } \\
\text { Values }\end{array}$ & $\begin{array}{c}\text { Leaf Photosynthetic } \\
\text { Rate }\end{array}$ & $\begin{array}{l}\text { SPAD } \\
\text { Values }\end{array}$ & & \\
\hline \multirow{4}{*}{ EGP } & Root length & $0.52 *$ & $0.68^{* *}$ & $0.70^{* *}$ & $0.79^{* *}$ & $0.66^{* *}$ & $0.80 * *$ & $0.59^{* *}$ & $0.84^{* *}$ \\
\hline & Root volume & 0.63 ** & 0.54 * & $0.83^{* *}$ & $0.71 * *$ & $0.74 * *$ & $0.77^{* *}$ & $0.52 *$ & $0.84^{* *}$ \\
\hline & Root oxidation activity & 0.25 & -0.11 & 0.43 & 0.14 & 0.40 & 0.29 & $0.65^{* *}$ & $0.48^{*}$ \\
\hline & Root bleeding rate & 0.25 & 0.17 & 0.29 & 0.32 & 0.33 & 0.41 & $0.48^{*}$ & 0.29 \\
\hline \multirow{3}{*}{ MGP } & Root length & 0.44 & 0.53 * & $0.67^{* *}$ & $0.68^{* *}$ & $0.74 * *$ & $0.73 * *$ & $0.68^{* *}$ & $0.77^{* *}$ \\
\hline & Root oxidation activity & $0.60 * *$ & 0.38 & $0.83^{* *}$ & 0.58 * & $0.75^{* *}$ & $0.65^{* *}$ & $0.67^{* *}$ & $0.83^{* *}$ \\
\hline & Root bleeding rate & 0.36 & 0.41 & $0.69 * *$ & 0.62 ** & $0.82 * *$ & $0.69^{* *}$ & 0.72 ** & $0.84^{* *}$ \\
\hline \multirow{4}{*}{ LGP } & Root length & 0.35 & $0.56^{*}$ & 0.60 ** & 0.73 ** & 0.72 ** & $0.79^{* *}$ & 0.70 ** & $0.76^{* *}$ \\
\hline & Root volume & $0.51 *$ & 0.66 & $0.74^{* *}$ & $0.76^{* *}$ & $0.76^{* *}$ & $0.75^{* *}$ & $0.66^{* *}$ & 0.92 ** \\
\hline & Root oxidation activity & 0.41 & 0.34 & $0.65^{* *}$ & 0.54 * & $0.65^{* *}$ & $0.62 * *$ & $0.74^{* *}$ & $0.84^{* *}$ \\
\hline & Root bleeding rate & $0.52 *$ & $0.59^{* *}$ & $0.75^{* *}$ & $0.75^{* *}$ & $0.78^{* *}$ & $0.80 * *$ & $0.69^{* *}$ & $0.90^{* *}$ \\
\hline
\end{tabular}

SPAD, soil-plant analysis development; EGP, early grain-filling period; MGP, middle grain-filling period; LGP, late grain-filling period. *, significant at $p<0.05$ level, and ${ }^{* *}$, significant at $p<0.01$ level. 


\section{Discussion}

Unsurprisingly, cultivar improvement greatly increased rice grain yield; the 2010's rice had $8.0 \%$ and $4.3 \%$ higher than the 1990's and the 2000's rice, respectively $(p<0.05)$ (Table 2). The contribution of yield components to genetic improvement of grain yield was reported, however, the results were not fully consistent. For example, the yield increment during the genetic improvement was attributable to the increased panicles per $\mathrm{m}^{2}$ in Japan [24], while to spikelets per panicle in central China [6] and synchronous increase in panicles per $\mathrm{m}^{2}$, spikelets per panicle, and filled-grain percentage in northeast China [5]. Here, our analysis on yield components demonstrated that genetic yield gain was mainly driven by spikelets per panicle (Table 2), consistent with Zhu et al. [6]. Besides, genetic improvement decreased sink-filling efficiency, especially for filled-grain percentage (Table 2). This information suggests that further exploration is still needed to improve synergistically panicle size and sink-filling efficiency in modern japonica inbred rice.

For rice, genetic yield gain was realized through improving shoot biomass [24], harvest index [25], or both [7,26]. In this study, the 2000's rice had a higher harvest index $(p<0.05)$, whereas a non-significant difference in shoot biomass at maturity $(p \geq 0.05)$, than the 1990's rice; the 2010's rice showed an increase in shoot biomass weight at maturity $(p<0.05)$, while it showed a non-significant increase in harvest index ( $p \geq 0.05)$, compared with the 2000's rice (Table 3). Our results suggested yield gain of rice released from the 1990s to 2000s was mainly attributed to harvest index, while higher shoot biomass contributed more to increased yield from the 2000s to 2010s. These results also indicated that future enhancement in rice yield potential relies more on biomass accumulation rather than on harvest index, considering the limited possibility to further increase harvest index [25,27].

Compared with the 1990's and the 2000's rice, the higher total shoot biomass weight of the 2010's rice was mainly reflected by shoot biomass accumulation from heading to maturity (Table 3), suggesting, again, the contribution of post-heading shoot biomass accumulation to grain yield $[28,29]$. The more shoot biomass accumulation after heading was greatly supported by root biomass after heading, given that the tight relationship existed between root and shoot in crops [22,30]. Similar to shoot biomass, the 2010's rice demonstrated consistently higher root biomass at heading and maturity than the 1990's and the 2000's rice $(p<0.05)$ (Table 3, Figure 1). Our results suggested that the 2010's rice had an improved root growth and a coordinated growth between the shoot and root after heading, which was strongly related to yield superiority in modern japonica inbred rice $(p<0.01)$ (Table 7).

It is reported that root morphology and physiology are strongly correlated to shoot growth and grain yield in crops $[15,23]$. Still, little attention has been paid to changes and differences of root characteristics during the genetic improvement of japonica inbred rice. The differences in root biomass weight among three cultivar types enlarged at heading and maturity, and the most pronounced change in root biomass was detected in 15-30 cm soil depth; the 2010's rice had higher root biomass of 15-30 cm depth compared with the 1990's and the 2000's rice $(p<0.05)$ (Table 4, Figure 1). This result implied that genetic progress increased root weight after heading, especially for deeper roots. Compared with the 1990's and the 2000's rice, the 2010's rice exhibited higher post-heading root length and volume, particularly at maturity $(p<0.05)$ (Table 6$)$. The post-heading higher root length and root volume of the 2010's rice could be interpreted by the lower root mortality, which was believed to be tightly associated with assimilate production and translocation from the shoot [31-33]. The present study demonstrated that the 2010's rice had consistently higher LAI, SPAD values, and leaf photosynthetic rate after heading than the 1990's and the 2000's rice (Table 5, Figure 2). These results indicated a better post-heading shoot stay-green of the 2010's rice, which would benefit carbon supply and translocation from the shoot to root, hence maintaining root growth after heading [34,35].

In this study, the 2010's rice exhibited higher root oxidation activity and root bleeding rate, especially at MGP and LGP, than the 1990's and the 2000's rice $(p<0.05)$ (Figure 3), implying better root physiology after heading of the 2010's rice. This result suggested 
that root morpho-physiology was improved during the genetic evolution of japonica inbred rice, which was similar to the conclusions reported in other crops, such as maize and wheat $[12,13,15]$. Correlation analysis presented positive correlations between root morpho-physiology after heading and leaf photosynthetic traits, as well as shoot biomass accumulation, from heading to maturity, and grain yield ( $p<0.05$ or $p<0.01$ ) (Table 8). Therefore, it could be reasonably inferred that the genetic process improved post-heading root morphology and physiology, which was associated with better shoot stay-green, more biomass accumulation after heading, and progressive yield gain of japonica inbred rice in east China since the 1990s.

The above results confirmed the contribution of post-heading root morphology and physiology to yield gain during the genetic improvement of japonica inbred rice. Such results also brought some implications in future breeding programs: (i) in our study, root biomass at heading correlated positively with shoot biomass at heading and maturity $(p<0.05$ or $p<0.01)$ as well as grain yield $(p<0.01)$ (Table 7$)$. This result suggested coordination of the root and shoot after heading was critical for maintaining grain yield of rice [11], and a well-established root system after heading could be used as a selection criterion for future rice root breeding. (ii) grain-filling duration is a crucial period for grain yield formation of cereals, similar to senescence phase of leaf and root, two important sources for sink filling [36]. As described previously, root length and volume, root oxidation activity, and root bleeding rate were closely associated with shoot stay-green and biomass accumulation after heading (Table 8). Hence, parents with superior root morphology-physiology should receive more attention for developing rice cultivars with higher yield potential.

\section{Conclusions}

The genetic improvement produced a $4.3-8.0 \%$ higher grain yield of the 2010 's rice than the 1990's and the 2000's rice, mainly attributed to the increase in spikelets per panicle. Yield gain from the 1990s to 2000s was attained by harvest index, while shoot biomass increased yield from the 2000s to 2010s. Compared with the 1990's and the 2000's rice, the 2010's rice had higher root biomass at heading and maturity, as well as root length and volume, root oxidation activity, and root bleeding rate after heading. Such improved root morpho-physiology after heading facilitated better shoot stay-green, and higher biomass accumulation and grain yield of modern japonica inbred rice.

Author Contributions: Conceptualization, T.M. and H.W.; methodology, T.M. and G.Z.; investigation, X.C., X.Z. and J.G.; data curation, G.Z.; writing—original draft preparation, T.M.; supervision, H.W.; project administration, Q.D. and H.W.; funding acquisition, Q.D. and H.W. All authors have read and agreed to the published version of the manuscript.

Funding: This research was funded by the National Natural Science Foundation of China (31901448, 32001466), and Postdoctoral Research Foundation of China (2020M671629).

Data Availability Statement: The data supporting the conclusions of this article are within the paper.

Acknowledgments: We thank Xu Zuopeng, Zhang Qing, and Li Gang for their help in collecting rice seeds.

Conflicts of Interest: The authors declare no conflict of interest.

\section{References}

1. Birla, D.S.; Malik, K.; Sainger, M.; Chaudhary, D.; Jaiwal, R.; Jaiwal, P.K. Progress and challenges in improving the nutritional quality of rice (Oryza sativa L.). Crit. Rev. Food Sci. 2017, 57, 2455-2481. [CrossRef] [PubMed]

2. Yuan, L.P. Development of hybrid rice to ensure food security. Rice Sci. 2014, 21, 1-2. [CrossRef]

3. Yu, Y.Q.; Huang, Y.; Zhang, W. Changes in rice yields in China since 1980 associated with cultivar improvement, climate and crop management. Field Crop Res. 2012, 136, 65-75. [CrossRef]

4. Breseghello, F.; de Morais, O.P.; Pinheiro, P.V.; Silva, A.C.S.; de Castro, E.M.; Guimarães, É.P.; de Castro, A.P.; Pereira, J.A.; Lopes, A.M.; Utumi, M.M.; et al. Results of 25 years of upland rice breeding in Brazil. Crop Sci. 2011, 51, 914-923. [CrossRef] 
5. Wu, Z.H.; Xu, K.Z.; Zhao, Y.J.; He, X.L.; Wang, X.L.; Ling, F.L. Changes of some agronomic traits in japonica rice varieties during forty-seven years of genetic improvement in Jilin province, China. Chin. J. Rice Sci. 2007, 21, 507-512.

6. Zhu, G.L.; Peng, S.B.; Huang, J.L.; Cui, K.H.; Nie, L.X.; Wang, F. Genetic improvements in rice yield and concomitant increases in radiation- and nitrogen-use efficiency in middle reaches of Yangtze River. Sci. Rep.-UK 2016, 6, 21049. [CrossRef]

7. Peng, S.; Laza, R.C.; Visperas, R.M.; Sanico, A.L.; Cassman, K.G.; Khush, G.S. Grain yield of rice cultivars and lines developed in the Philippines since 1966. Crop Sci. 2000, 40, 307-314. [CrossRef]

8. Tabien, R.E.; Samonte, S.O.P.B.; McClung, A.M. Forty-eight years of rice improvement in Texas since the release of cultivar Bluebonnet in 1944. Crop Sci. 2008, 48, 2097-2106. [CrossRef]

9. Yamamoto, T.; Suzuki, T.; Suzuki, K.; Adachi, S.; Sun, J.; Yano, M.; Ookawa, T.; Hirasawa, T. Characterization of a genomic region that maintains chlorophyll and nitrogen contents during ripening in a high-yielding stay-green rice cultivar. Field Crop Res. 2017, 206, 54-64. [CrossRef]

10. Zhu, G.L.; Ren, Z.; Liu, Y.Q.; Lu, F.G.; Gu, L.F.; Shi, Y.; Liu, J.W.; Zhou, G.S.; Nimir, N.E.A.; Mohapatra, P.K. Optimization of leaf properties and plant phenotype through yield-based genetic improvement of rice over a period of seventy years in the Yangtze River basin of China. Food Energy Secur. 2020, 9, e223. [CrossRef]

11. Rogers, E.D.; Benfey, P.N. Regulation of plant root system architecture: Implications for crop advancement. Curr. Opin. Biotechnol. 2015, 32, 93-98. [CrossRef]

12. Ning, P.; Li, S.; Li, X.X.; Li, C.J. New maize hybrids had larger and deeper post-silking root than old ones. Field Crop Res. 2014, 166, 66-71. [CrossRef]

13. Zhang, Y.K.; Chen, F.J.; Chen, X.C.; Long, L.Z.; Gao, K.; Yuan, L.X.; Zhang, F.S.; Mi, G.H. Genetic improvement of root growth contributes to efficient phosphorus acquisition in maize (Zea mays L.). J. Integr. Agric. 2013, 12, 1098-1111. [CrossRef]

14. Cui, X.; Dong, Y.; Gi, P.; Wang, H.; Xu, K.; Zhang, Z. Relationship between root vigour, photosynthesis and biomass in soybean cultivars during 87 years of genetic improvement in the northern China. Photosynthetica 2016, 54, 81-86. [CrossRef]

15. Palta, J.A.; Chen, X.; Milroy, S.P.; Rebetzke, G.J.; Dreccer, M.F.; Watt, M. Larger root systems: Are they useful in adapting wheat to dry environments. Funct. Plant Biol. 2011, 38, 347-354. [CrossRef]

16. Tian, Z.W.; Fan, Y.H.; Yin, M.; Wang, F.R.; Cai, J.; Jiang, D.; Dai, T.B. Genetic improvement of root growth and its relationship with grain yield of wheat cultivars in the middle-lower Yangtze River. Acta Agron. Sin. 2015, 41, 613-622. [CrossRef]

17. Zhang, H.; Huang, Z.H.; Wang, J.C.; Wang, Z.Q.; Yang, J.C. Changes in morphological and physiological traits of roots and their relationships with grain yield during the evolution of mid-season indica rice cultivars in Jiangsu Province. Acta Agron. Sin. 2011, 37, 1020-1030. [CrossRef]

18. Zhang, H.C.; Zhang, J.; Gong, J.L.; Chang, Y.; Li, M.; Gao, H.; Dai, Q.G.; Huo, Z.Y.; Xu, K.; Wei, H.Y. The productive advantages and formation mechanisms of "indica rice to japonica rice". Sci. Agric. Sin. 2013, 46, 686-704.

19. Wang, C.L.; Zhang, Y.D.; Zhu, Z.; Chen, T.; Zhao, Q.Y.; Zhong, W.G.; Yang, J.; Yao, S.; Zhou, L.H.; Zhao, L.; et al. Research progress on the breeding of japonica super rice varieties in Jiangsu Province, Chin. J. Integr. Agric. 2017, 16, 992-999. [CrossRef]

20. Wang, W.T.; Cui, W.P.; Xu, K.; Gao, H.; Wei, H.Y.; Zhang, H.C. Effects of early- and late-sowing on starch accumulation and associated enzyme activities during grain filling stage in rice. Rice Sci. 2021, 28, 191-199.

21. Zhang, W.Y.; Yu, J.X.; Xu, Y.J.; Wang, Z.Q.; Liu, L.J.; Zhang, H.; Gu, J.F.; Zhang, J.H.; Yang, J.C. Alternate wetting and drying irrigation combined with the proportion of polymer-coated urea and conventional urea rates increases grain yield, water and nitrogen use efficiencies in rice. Field Crop Res. 2021, 268, 101865. [CrossRef]

22. Ando, T.; Yoshida, S.; Nishiyama, I. Nature of oxidizing power of rice roots. Plant Soil 1983, 72, 57-71. [CrossRef]

23. Meng, T.Y.; Wei, H.H.; Li, X.Y.; Dai, Q.G.; Huo, Z.Y. A better root morpho-physiology after heading contributing to yield superiority of japonica/indica hybrid rice. Field Crop Res. 2018, 228, 135-146. [CrossRef]

24. Anzoua, K.G.; Junichi, K.; Toshihiro, H.; Kazuto, I.; Yutaka, J. Genetic improvements for high yield and low soil nitrogen tolerance in rice (Oryza Sativa L.) under a cold environment. Field Crop Res. 2010, 116, 38-45. [CrossRef]

25. Saito, H.; Fukuta, Y.; Obara, M.; Tomita, A.; Ishimaru, T.; Sasaki, K.; Fujita, D.; Kobayashi, N. Two novel QTLs for the harvest index that contribute to high-yield production in rice (Oryza sativa L.). Rice 2021, 14, 18. [CrossRef]

26. Liu, L.L.; Wang, E.L.; Zhu, Y.; Tang, L.; Cao, W.X. Effects of warming and autonomous breeding on the phenological development and grain yield of double-rice systems in China. Agric. Ecosyst. Environ. 2013, 165, 28-38. [CrossRef]

27. Jiang, Y.; Qian, H.Y.; Wang, L.; Feng, J.F.; Huang, S.; Hungate, B.A.; van Kessel, C.; Horwath, W.R.; Zhang, X.Y.; Qin, X.B.; et al. Limited potential of harvest index improvement to reduce methane emissions from rice paddies. Glob. Chang. Biol. 2019, 25, 686-698. [CrossRef]

28. Marcaida, M., III; Li, T.; Angeles, O.; Evangelista, G.K.; Fontanilla, M.A.; Xu, J.L.; Gao, Y.M.; Li, Z.K.; Ali, J. Biomass accumulation and partitioning of newly developed Green Super Rice (GSR) cultivars under drought stress during the reproductive stage. Field Crop Res. 2014, 162, 30-38. [CrossRef]

29. Niones, J.M.; Suralta, R.R.; Inukai, Y.; Yamauchi, A. Field evaluation on functional roles of root plastic responses on dry matter production and grain yield of rice under cycles of transient soil moisture stresses using chromosome segment substitution lines. Plant Soil 2012, 359, 107-120. [CrossRef]

30. Atere, C.T.; Ge, T.; Zhu, Z.K.; Liu, S.L.; Huang, X.Z.; Shibsitova, O.; Guggenberger, G.; Wu, J.S. Assimilate allocation by rice and carbon stabilisation in soil: Effect of water management and phosphorus fertilization. Plant Soil 2019, 445, 153-167. [CrossRef] 
31. Madhu, M.; Hatfield, J.L. Dynamics of plant root growth under increased atmospheric carbon dioxide. Agron. J. 2013, 105, 657-669. [CrossRef]

32. Zang, H.D.; Xiao, M.L.; Wang, Y.D.; Ling, N.; Wu, J.S.; Ge, T.; Kuzyakov, Y. Allocation of assimilated carbon in paddies depending on rice age, chase period and $\mathrm{N}$ fertilization: Experiment with ${ }^{13} \mathrm{CO}_{2}$ labelling and literature synthesis. Plant Soil 2019, 445, 113-123. [CrossRef]

33. Kobata, T.; Shinonaga, M.; Yoshida, H.; Tomisaka, K.; Akai, K. Stay-green trait assessment using the leaf incubation method to examine the maintenance of assimilation rates under high temperature conditions during the grain-filling period in rice. Plant Prod. Sci. 2015, 18, 254-266. [CrossRef]

34. Shin, D.; Lee, S.; Kim, T.H.; Lee, J.H.; Park, J.; Lee, J.Y.; Cho, L.H.; Choi, J.Y.; Lee, W.; Park, D.W.; et al. Natural variations at the Stay-Green gene promoter control lifespan and yield in rice cultivars. Nat. Commun. 2020, 11, 2819. [CrossRef]

35. Dass, A.; Chandra, S.; Choudhary, A.K.; Singh, G.; Sudhishri, S. Influence of field re-ponding pattern and plant spacing on rice root-shoot characteristics, yield, and water productivity of two modern cultivars under SRI management in Indian Mollisols. Paddy Water Environ. 2016, 14, 45-59. [CrossRef]

36. Wei, H.H.; Meng, T.Y.; Li, X.Y.; Dai, Q.G.; Zhang, H.C.; Yin, X.Y. Sink-source relationship during rice grain filling is associated with grain nitrogen concentration. Field Crop Res. 2018, 215, 23-38. [CrossRef] 